\title{
Basel III, risk aversion and bank performance: evidence from Chinese commercial banks panel data
}

\author{
Qin SONG ${ }^{1, a}$, Wei ZENG ${ }^{2, b}$ \\ ${ }^{12}$ Central China Nomal University, China \\ asongqin2006phd@sina.com.cn, b465377625@qq.com
}

Keywords: Z-score; risk aversion; bank performance

\begin{abstract}
The bank supervision in China promotes four instruments coming from Basel III standards announced from Basel committee. What effects will it have on Chinese commercial banks? This paper develops models with a sample of 29 commercial banks in China by measuring risk aversion with Z-score, and finds that: Z-score is positive to capital adequacy ratio and negative to liquid ratio significantly; performance is positive to liquid ratio, Z-score is negative to loan loss reservation ratio significantly. It suggests that the four instruments are good for increasing Z-score, reducing solvency probability and stimulating bank performance.
\end{abstract}

\section{Introduction}

Based on the lessons from the global financial crisis, financial regulators pay more attention to the stability of the banking system and soundness of banking development. However, bank management has to focus on ways to improve business performance. Recently, Basel Committee's Basel III regulatory standards revised require banks to raise the minimum capital adequacy, including raising the minimum common equity capital, from $2 \%$ to $4.5 \%$; capital protection buffer of $2.5 \%$; to promote the establishment of buffer capital (protective buffer capital and counter-cyclical capital buffers); leverage an initial period of 3\%; the introduction of minimum standards of global liquidity, including short-term structural liquidity coverage ratio (LCR) and the net long-term structural stability of financing ratio (NSFR). The financial regulatory standards will lead to changes in bank risk-taking.

The relationship between Capital regulation and bank risk-taking seems to be no consistent. Capital regulation will lead banks to reconfigure their assets, may increase risk-taking (Koehn and Santomero, 1980) [6]. The risk weight corrected in theory will reduce risk-taking (Kim and Santomero, 1988) [7]. In some cases, banks are likely to become risk-lovers in limited liability, the minimum capital ratio to ensure that banks take prudent actions (Rochet, 1992) [12]. Higher capital requirements reduce the incentives for a bank to increase asset risk, there with reducing the risk exposure of the deposit insurance system. (Furlong and Keeley, 1989) [4]. The latest research does not support the strict capital regulation is negative to bank risk-taking. Capital regulation may not reduce bank risk-taking (Laeven and Levin, 2009) [9].

Bank supervision always requires banks to maintain certain capital buffer (Shrieves and Dahl, 1992; Kleff and Weber, 2008) [13] [8]. Short-term capital buffered is positive to portfolio risk (Terhi and Alistair, 2010) [14]. The atrophy in Lower capital buffer of bank loans is larger than in higher (Merkl and Stolz, 2006) [10]. Deviation from the optimal risk weights, limited leverage and risk-based capital ratio is more suitable for control the bank asset risk (Gjerde and Semmen, 1995) [5]. Bikker and Metzemakers (2004) find that the bank's capital has little pro-cyclical [3]. But Adrian and Shin (2009) suggest that leverage ratio has a strong pro-cyclical in sample of six major U.S. investment banks [1].

As far as we know, it exists that how to incent guard against bank run and creditor. Bankruptcy policy should be matched with a strong asset monitoring for failure banks to strictly limit their risk selection. Incentive compatibility of the banking regulatory system, based on moral hazard and adverse selection, may solve the incentive problem and achieve optimal results depending on bank performance (Nagarajan and Sealey, 1998) [11]. Over-reliance on direct banking supervision is not 
good for improving operational efficiency. Appropriate information disclosure and private sector monitoring banks, are also an effective way (Barth, Caprio and Levine, 2004) [2].

The main innovation of this paper is to measuring risk averse by Z-score with developing models from Chinese commercial banks firstly. The remainder of this paper is presented as follows. The Section II consists of data and methodology. The Section III discusses empirical results. The Section IV is summary.

\section{Data and methodology}

This paper selects 29 commercial banks from 2004 to 2008, including Industrial \& Commercial Bank of China, Agricultural Bank of China, China Construction Bank, Bank of China, Bank of Communications, China CITIC Bank, China Merchants Bank, China Minsheng Bank, Industrial Bank, Shanghai Pudong Development Bank, Guangdong Development Bank, Shenzhen Development Bank, China Everbright Bank, Hua Xia Bank, Zheshang Bank, Bank of Nanjing, Ping An Bank, Bank of Ningbo, Bank of Shanghai, Bank of Tianjin, Bank of Chongqing, Bank of Hangzhou, Bank of Dalian, Dongguan Bank, Hankou Bank, Evergrowing Bank, Huishang Bank, Bank of Jiangsu, Qilu Bank. Financial data of 29 banks is from Bankscope. This paper focus on Z,equity ,lr,tcr,llr,ld,npl and ROAE variables as table 1. The panel data is estimated by Hausman tests, GLS and MLE estimation.

Table 1 Variable

\begin{tabular}{ll}
\hline variables & calculation \\
\hline $\mathrm{Z}$ & $\mathrm{Z}=\left(\mathrm{CAR}+\mu_{\mathrm{ROA}}\right) / \sigma_{\mathrm{ROA}}$ \\
equity & equity=total assets-liability \\
$\mathrm{lr}$ & lr=liquid assets/Dep\&ST funding \\
$\mathrm{tcr}$ & tcr=total capital /weighted risk assets \\
$\mathrm{llr}$ & llr=loan loss res/gross loans \\
$\mathrm{ld}$ & ld=net loans/Dep\&ST funding \\
$\mathrm{npl}$ & npl=impaired loans/gross loans \\
ROAE & roae=return/equity \\
\hline
\end{tabular}

As can be seen in Table 2, the mean of $\mathrm{Z}$ is 107.188, the standard deviation value is 352.3906 . The mean of liquid ratio is $19.31806 \%$, and the standard deviation value is $19.31806 \%$. The mean of loan to deposit ratio is $57.88937 \%$, and the standard deviation value is 7.504933 . The mean of loan loss reservation ratio is $2.897273 \%$, and the standard deviation value is $2.48128 \%$. The mean of total capital ratio is $10.09696 \%$, and the standard deviation value is $4.156741 \%$. The mean of the mean of non-preferment ratio $3.876977 \%$ and the standard deviation value is $4.836691 \%$. The mean of equity is 58158.74 million RMB, and he standard deviation value is 124274.6 million RMB.

Table 2 Summary statistics

\begin{tabular}{llllll}
\hline Variable & Mean & St.dev & Minimum & Maximum & Oberservations \\
\hline $\mathrm{Z}$ & 107.188 & 352.3906 & -44.9537 & 3104 & 138 \\
$\mathrm{lr}$ & $19.31806[\%]$ & $4.983581[\%]$ & $8.25[\%]$ & $31.53[\%]$ & 144 \\
$\mathrm{ld}$ & $57.88937[\%]$ & $7.504933[\%]$ & $42.75[\%]$ & $75.82[\%]$ & 143 \\
$\mathrm{llr}$ & $2.897273[\%]$ & $2.48128[\%]$ & $0.68[\%]$ & $22.02[\%]$ & 143 \\
$\mathrm{tcr}$ & $10.09696[\%]$ & $4.156741[\%]$ & $-1.50[\%]$ & $30.10[\%]$ & 125 \\
$\mathrm{npl}$ & $3.876977[\%]$ & $4.836691[\%]$ & $0.03[\%]$ & $26.73[\%]$ & 129 \\
equity & $58158.74[\mathrm{million}$ & 124274.6 & $261[\mathrm{million}$ & $606636[\mathrm{million}$ & 135 \\
& RMB] & & RMB] & RMB] & \\
\hline
\end{tabular}




\section{Empirical results}

As the results of table 3 , we know that $\mathrm{P}$ value is 0.1718 , which doesn't reject null hypothesis, so we choose random effect model.

Table 3 Hausman tests

\begin{tabular}{ccccc}
\hline $\operatorname{lnz} 1$ & $\mathrm{~b}($ fixed) & $\mathrm{B}($ random) & $\mathrm{b}-\mathrm{B}$ & Sqrt(diag(v_b-v_B)) \\
\hline $\mathrm{lr}$ & -0.0226669 & -0.0565387 & 0.0338718 & 0.0233767 \\
$\mathrm{tcr}$ & 0.0002078 & 0.0634466 & -0.0632389 & 0.0655393 \\
$\mathrm{ld}$ & 0.0546303 & 0.0254402 & 0.0291901 & 0.0303298 \\
$\mathrm{npl}$ & -0.0820582 & -0.0473909 & -0.0346673 & 0.055279 \\
llr & 0.3336755 & 0.1398623 & 0.1938132 & 0.1826775 \\
lnequity & 0.3214995 & -0.1121636 & 0.4336631 & 0.4681237 \\
\hline
\end{tabular}

$\mathrm{H}_{0}$ : difference in coefficients not systematic, chi $^{2}(6)=(b-B)^{\prime}\left[\left(V_{-} b-V_{-} B\right)^{\wedge}(-1)\right](b-B)==$ 9.03, Prob $>\mathrm{chi}^{2}=0.1718$.

As can be seen in Table 4, liquid ratio and total capital ratio is significant at $10 \%$. Liquid ratio is negative to Z-score. Total capital ratio is positive to Z-score, increase capital ratio, lower solvency probability. However, loan loss reservation ratio, non-preferment ratio, loan to deposit ratio, logram equity is not significant to Z-score because Chinese solvency law is not completed and deposit insurance institute is absent.

Table 4 Coefficients of model

\begin{tabular}{ccc}
\hline $\operatorname{lnz}$ & GLS & MLE \\
\hline constant & $3.352482^{* * *}$ & $3.411316^{* * *}$ \\
lr & $-0.0565387^{* *}$ & $-0.0589287^{* *}$ \\
tcr & 0.0634466 & $0.0633787^{*}$ \\
ld & 0.0254402 & 0.0250464 \\
npl & -0.0473909 & -0.0462755 \\
llr & 0.1398623 & 0.1391709 \\
lnequity & -0.1121636 & -0.1110879 \\
statistics & Wald chi $^{2}=9.10$ & LR chi $^{2}=9.69$ \\
\hline & $\mathrm{R}^{2}:$ between $=0.0295 ;$ within $=0.2488 ;$ average & Log likelihood $=-166.7728$ \\
& $=0.0870$ & \\
\hline
\end{tabular}

Notes:*, **denotes significant at $10 \%$ and 5\% level.

How does $\mathrm{Z}$ impact on bank performance? ROAE is explained variable and develop model. As can be seen in Table5, $\mathrm{P}$ value is 0.8126 from the results of Hausman test,which doesn't reject null hypothesis,so we choose random effect model.

Table 5 Hausman tests

\begin{tabular}{ccccc}
\hline ROAE & b(fixed) & B(random) & b-B & Sqrt(diag(v_b-v_B)) \\
\hline $\operatorname{ll} r$ & -3.575527 & -4.034509 & 0.4589826 & 1.211344 \\
$\ln z$ & 2.772248 & 3.486658 & -0.7144099 & 0.7660619 \\
$\operatorname{lr}$ & 1.13812 & 1.038732 & 0.0993889 & 0.2016034 \\
\hline
\end{tabular}

$\mathrm{H}_{0}$ : difference in coefficients not systematic,chi ${ }^{2}(3)=(\mathrm{b}-\mathrm{B})^{\prime}\left[\left(\mathrm{V} \_\mathrm{b}-\mathrm{V} \_\mathrm{B}\right)^{\wedge}(-1)\right](\mathrm{b}-\mathrm{B})=0.95$, Prob $>\mathrm{chi}^{2}=0.8126$.

As can be seen in Table 6, liquid ratio, $\mathrm{Z}$-score, loan loss reservation ratio is positive to ROAE significantly at $5 \%$. The empirical results denote that more risk adverse greatly, higher bank performance. Greater risk adverse, stable and rational bank could get better return. 
Table 6 Coefficients of model

\begin{tabular}{|c|c|c|}
\hline ROAE & GLS & MLE \\
\hline constant & -8.954467 & -9.016363 \\
\hline llr & $-4.034509^{* * *}$ & $-4.048225^{* * *}$ \\
\hline $\operatorname{lnz} 1$ & $3.486658^{* *}$ & $3.584018^{* * *}$ \\
\hline $\ln$ & $1.038732^{* * *}$ & $1.029245^{* * *}$ \\
\hline statistics & Wald $\mathrm{chi}^{2}=22.02^{* * *}$ & $\mathrm{LR}_{\mathrm{chi}^{2}}{ }^{2} 21.23^{* * *}$ \\
\hline & $\mathrm{R}^{2}$ : between $=0.1294$; within $=0.2282 ;$ average $=0.1536$ & Log likelihood $=-586.47539$ \\
\hline
\end{tabular}

\section{Summary}

This paper examines Chinese bank supervision promotes four instruments of Basel III standards impact on Chinese commercial banks. This paper develops models with a sample of 29 commercial banks in China by measuring risk averse with Z-score. It finds that Z-score is positive to capital adequacy ratio and negative to liquid ratio significantly, and performance is positive to liquid ratio, $\mathrm{Z}$-score is negative to loan loss reservation ratio significantly. Meanwhile, the four instruments are good for increasing Z-score, reducing solvency probability and stimulating bank performance. The bank supervision in China take practice Basel III standards begging at January 1 in 2013. More and more commercial banks join in to find how to apply Basel III accords in business, which is helpful for Chinese financial system soundness.

\section{References}

[1] T. Adrian, H.S. Shin, Financial Intermediaries and Monetary Economics[EB/OL]. http://www.newyorkfed.org/research/staff_reports/sr398.pdf/2009.

[2] J.R. Barth, G. Caprio, R. Levine, Bank Regulation and Supervision: What Works Best, Journal of Finance Intermediary. 13 (2004) 205-248.

[3] J.A. Bikker, P.A.J. Metzemakers, Is Bank Capital Pro-Cyclical? A Cross-country Analysis [EB/OL]. http://econpapers.repec.org/paper/dnbdnbwpp/009.htm/2004.

[4] F.T. Furlong, M.C. Keeley, Capital Regulation and Bank Risk-taking: A Note ,Journal of Bank Finance. 13 (1989) 883-891.

[5] O. Gjerde, K. Semmen, Risk-based Capital Requirements and Bank Portfolio Risk, Journal of Banking and Finance. 19 (1995) 1159 - 1173.

[6] M. Koehn, A.M. Santomero, Regulation of Bank Capital and Portfolio Risk ,Journal of Finance.35 (1980) 1235-1244.

[7] D. Kim, A.M . Santomero, Risk in Banking and Capital Regulation , Journal of Finance.43 (1988) 1219-1233.

[8] V. Kleff, M. Weber, How Do Banks Determine Capital? Evidence from Germany , German Economic Review. 9 (2008) 354-372.

[9] L. Laeven, R. Levine, Corporate Governance, Regulation and Bank Risk-taking, Journal of Finance Economics.93 (2009): 259-275.

[10] C. Merk1, S. Stolz, Banks’ Regulatory Buffers, Liquidity Networks and Monetary Policy Transmission [EB/OL]. http://econpapers.repec.org/paper/zbwbubdp2/4771.htm/2006.

[11] S. Nagarajan, C.W. Sealey, State-contingent Regulatory Mechanisms and Fairly Priced Deposit Insurance ,Journal of Banking and Finance. 22 (1998) 1139-1156. 
[12] J.C. Rochet, Capital Requirements and the Behavior of Commercial Banks, European Economics Review.36 (1992)1137-1178.

[13] R. Shrieves, D. Dahl, The Relationship between Risk and Capital in Commercial Banks ,Journal of Banking and Finance.16 (1992)439-457.

[14] J. Terhi, M. Alistair, Bank Capital Buffer and Risk Adjustment Decisions, Journal of Financial Stability. 7 (2010)165-178. 